\title{
STUDI KASUS PENERAPAN VENDOR MANAGED INVENTORY PADA SISTEM RANTAI PASOK
}

\author{
CASE STUDY OF VENDOR MANAGED INVENTORY APPLICATION \\ IN A SUPPLY CHAIN SYSTEM
}

\author{
Ricky Virona Martono \\ Sekolah Tinggi Manajemen PPM, \\ Jalan Menteng Raya 9, Jakarta, 10340, Indonesia \\ E-mail:RIC@ppm-manajemen.ac.id
}

\begin{abstract}
Vendor Managed Inventory (VMI) is an approach in managing inventory between supplier and consumer in an supply chain system. In VMI concept, supplier keeps its inventory at consumer's warehouse, meanwhile inventory ownership belong to supplier until it is used by consumer. The advantage of VMI is to reduce inventory replenishment ordering process and to reduce the usage of consumer's warehouse space. Some key factors to achieve VMI success are: coordination, communication, production system and inventory order reliability. When supplier is a subsidiary of consumer, coordination between the two usually puts them not at an equivalent level, especially when supplier's infrastructure is not as good as that at consumer. This research is a case study at a pharmaceutical company and its supplier which acts as its subsidiary. Information and data gathered by deep interview to all parties responsible for supply chain, production, and inventory at supplier and consumer sides. The results show advantages and obstacles in applying VMI, thus long-term conimitment is needed to reach a better performance.

Keywords: vendor managed inventory, collaboration, single level analysis.

Abstrak

Konsep Vendor Managed Inventory (VMI) merupakan salah satu pendekatan dalam mengelola inventori yang efisien antara pemasok dan konsumen di dalam sebuah sistem rantai pasok. Dengan VMI, pemasok menempatkan inventorinya di konsumen, naman kepernilikan inventori berpindah kepada konsumen ketika inventori digunakan. Keuntungan menerapkan VMI dicantaranya/adalah mengurangi proses pemesanan inventori dan mengurangi pemakaian ruang penyimpanan inventori di pemasok. Untuk mencapai ini dibutuhkan koordinasi, komunikasi, dan kehandalan sistem produksi dan pemesanan inventori yang tangguh untuk menerapkan VMI. Dalam kondisi dimana pemasok merupakan anak perusahaan dari konsumen, maka koordinasi tidak selalu menempatkan pemasok dan konsumen pada posisi setara. Terlebih ketika infrastruktur pemasok tidak sekuat konsumen. Penelitian ini dikhususkan pada sìdi kasus di sebuah perusahaan farmasi dan pemasoknya dimana pemasok merupakan anak perusahaannya. Informasi diperoleh melalui wawancara kepada pihak terkait di pemasok dan konsumen. Hasil pengamatan menunjukkan kelebihan dan hambatan dalam menerapkan VMI, sehingga dibutuhkan komitmen jangka panjang untuk mencapai keberhasilan yang lebih baik.
\end{abstract}

Kata kunci: vendor managed inventory, kolaborasi, single level analysis

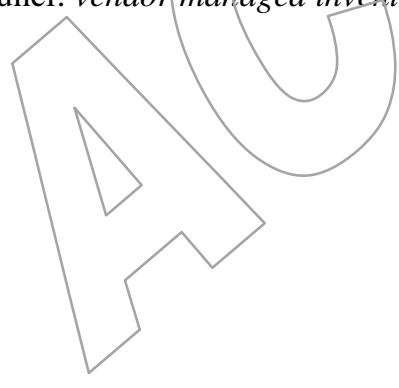




\section{PENDAHULUAN}

Tujuan keseluruhan elemen di dalam rantai pasok adalah menyediakan barang jadi kepada pasar sekaligus meningkatkan keuntungan perusahaan (Harrison, 2012). Proses dari pengolahan bahan mentah menjadi barang jadi, sampai diterima konsumen melibatkan banyak perusahaan. Setiap perusahaan ini berusaha mencapai keuntungannya, dimana salah satu langkahnya dengan menurunkan biaya proses. Persaingan sebuah rantai pasok menuntut semua perusahaan berkoordinasi dalam mengefisienkan prosesnya, yang mana pada akhirnya menurunkan biaya (Simchi-Levi, 2014).

Salah satu bentuk koordinasi di dalam rantai pasok dalam menurunkan biaya inventori, sekaligus menjamin tingkat ketersediaan inventori adalah Vendor Managed inventory (Vigtil, 2014). Vendor Managed Inventory (VMI) bertujuan mengisi ketersediaan inventori dari pemasok ke konsumen, dimana pemasok memiliki wewenang dan tanggungjawab akan ketersediaan barang di konsumen. Namun ada risiko berupa pembagian tanggungjawab ketika inventori sudah masuk ke lokasi konsumen tapi belum dikonsumsi. Sebelum melaksanakan VMI, pihak-pihak terkait wajib menyepakati siapa yang mengawasi, bagaimana membagi pembayaran asuransi inventori, bagaimana mempertahankan kualitas inventori sbahkaetelah diterima konsumen sampai digunakan konsumen. Maka, menerapkan VMI butuh kolaborasi yang kuat antara pemasok dan konsumen, koordinasi informasi, sistem pembayaran inventori, pembagian tanggungjawab dan risiko yang jelas diantara pemasok dan konsumen. Kolaborasi rantai pasok antar perusahaan yang bernaung di bawah satu organisasi akan menjadi lebih kuat dibanding beberapa perusahaan yang berdiri sendiri (Vigtil, 2014).

Beberapa penelitian telah membuktikan faktor-faktor penunjang keberhasilan kolaborasi pemasok dan konsumen
(Lockström et al., 2010). Penelitian mengenai VMI pernah dilakukan pada industri farmasi (Elvander, 2007). Namun, belum mengerucut pada industri farmasi di Indonesia dan kolaborasi dimana pemasok dan konsumen berada/pada satu induk perusahaan yang sama.

Studi yang pernah dilakukan pada industri ritel menyatakan bahwa kunci keberhasilan VMI lebih banyak di pihak pemasok (Sitornpul, 2012). Studi lain menunjukkan bahwa anak perusahaan kurang memperoleh benefit dar penerapan VMI (Elvander, 2007).

Penelitian ini membahas keberhasilan dan risiko menerapkan VMI pada salah satu industri farmasi Indonesia dimana setiap pihak dalam rantai pasok dibawahi oleh perusahaan induk yang sama. Industri ini menarik dibahas karena produknya mudah diperoleh oleh masyarakat, harga terjangkau, sehingga tingkat ketersediaannya di pasar harus tinggi. Pada studi kasus ini, pemasok dan konsumen berada di bawah grup perusahaan yang sama, dimana justru konsumen berperan sebagai perusahaan induk. Sehingga, konsumen pun seharusnya ikut banyak berperan. Maka penelitian ini ditujukan untuk menjawab pertanyaan: Apakah kunci keberhasilan dan penghambat dalam menerapkan VMI di dalam sebuah rantai pasok?

\section{TINJAUAN TEORI}

Kegiatan di dalam sebuah rantai pasok secara umum terdiri dari: penagihan, permintaan, produksi, inventori, distribusi, dan aliran informasi melalui setiap elemen di rantai pasok (Simchi-Levi, 2014). Yang dimaksud pemasok dan konsumen disini dapat berarti: pemasok dan produsen, produsen dengan distributor, atau distributor dengan penjual. 
Dari sudut pandang pengisian inventori, kesatuan dari seluruh kegiatan-kegiatan tersebut membentuk kolaborasi yang disebut dengan Customer Relations Management (CMR) atau Supplier Relations Management (SRM) (Simchi-Levi, 2014). Dalam sudut pandang efisiensi pengisian dan ketersediaan inventori, tanpa meningkatkan biaya akrual, strategi yang digunakan adalah Vendor Managed Inventory (VMI). Ketika koordinasi tidak berjalan baik, inventori akan bertambah dan menghambat efisiensi biaya dari aliran bahan jadi dan barang mentah. Sekitar $60 \%$ dari isu biaya dari rantai pasok sendiri adalah mengelola inventori (Ellinger, 2013). Inventori ini bisa berupa bahan mentah maupun barang jadi.

Salah satu strategi dalam mengelola biaya dan tingkat ketersediaan inventori adalah konsep Vendor Managed Inventory (VMI) yang diterapkan pada tahun 1980an dalam kerjasama antara Wal-Mart dengan Procter \& Gamble (Simchi-Levi, 2014). Ide dasarnya diperkenalkan oleh John F. Magee dengan diskusinya mengenai pihak yang seharusnya mengontrol inventori, apakah organisasi yang menggunakan inventori atau organisasi yang memasok inventorí. Menurut Magee, kedua pihak bertanggungjawab menjaga inventori dan pemasok harus menngawasi ketersediaan inventori berdasarkan informasi yang disediakan konsumen.

Dengan konsep VMI, inventori secara fisik disimpan di konsumen, tapi kepemilikan masih sebagai aset pemasok sampai inventori digunakan. Secara berkala, pemasok memantau pemakaian inventori yang disimpan di konsumen. Ketika ketersediaan inventori sudah mencapai titik tertentu, pemasok segera mengirim inventori sesuai jumlah yang disepakati bersama konsumen. Jumlah yang dikirim ini disesuaikan dengan kebutuhan konsumen, lead time pengiriman, dan ketersediaan ruang menyimpan inventori (Vigtil, 2014). Konsumen tidak perlu melakukan pemesanan barang dan pemasok tidak perlu menunggu order dari konsumen untuk menginisiasi pengisian inventori di konsumen.

Order yang diterima pemasok sampai pemasok melakukan pengisian inventori di konsumen membutuhkan lead time. Untuk antisipasi variasi lead time terhadap pemakaian inventori, maka jumlah inventori di konsumen ditambahkan dengan sejumlah sediaan pengaman (safety stock). Dengan demikian, pengisian inventori dengan sistem VMI juga mempertimbangkan jumlah safety stock. Setelah inventori dipakai konsumen, kepemilikan inventori beralih dari pemasok ke konsumen. Pembayaran dari konsumen kepada pemasok dilakukan pada setiap batas waktu penutupan laporan keuangan bulanan.

Keuntungan menerapkan VMI adalah pengurangan proses keputusan pemesanan inventori (Sinchi-Levi, 2014), menghilangkan kesalahan penyampaian informasi sehingga meningkatkan transparansi data (Mattson. 2012) dan permintaan konsumen dari konsumen akhir (Waller, M. Johnson. 2009), pengiriman inventori tepat waktu, dan menyesuaikan aliran inventori sesuai kebutuhan konsumen (Lapide, 2011). Konsumen memperoleh keuntungan dari VMI dengan ketersediaan inventori lebih baik sekaligus menangani lebih sedikit prosedur penanganan inventori Waller, M. Johnson. 2009). Sedangkan keuntungan bagi pemasok adalah berkurangnya penyimpanan fisik inventori (Mattson. 2012).

Namun perlu diperhatikan bahwa VMI hanya dapat meningkatkan service level ketika pemasok dan konsumen memiliki konsep perhitungan inventori yang sama (terkait tingkat re-order point, lead time, service level, jumlah pengisian kembali inventori) dan kesepakatan penanganan risiko terhadap inventori (McBeath, Bill. 2012).

Keuntungan menerapkan VMI memunculkan juga rintangan dan risiko 
yang menyertainya. Karena pemasok mengatur pengisian inventori di konsumen, maka kinerja konsumen tergantung dari disiplin pemasok dan rentan dengan tingkat kepercayaan konsumen kepada pemasok (Harrison, Van Hoek, 2012). Ketika inventori diterima konsumen namun kepemilikan masih ditangan pemasok, muncul isu mengenai pertanggungan biaya inventori dan risk sharing, misalnya: bagaimana sistem pembiayaan asuransi dan pajak inventori, bagaimana pertanggungjawaban jika inventori rusak atau hilang (Mattson, 2012). Kolaborasi dan kepercayaan ini mempengaruhi kemauan pemasok dan konsumen untuk saling berbagi informasi yang akurat (Whang, 2010). Informasi ini kadangkala bersifat rahasia, namun mengandung informasi faktor keberhasilan operasional, produksi, dan inventori pemasok dan konsumen. Tentunya faktor-faktor keberhasilan di konsumen harus sejalan dengan faktor keberhasilan di pemasok (McBeath 2012).

Sistem informasi pendukung ini tidak jarang membutuhkan biaya tinggi, prosedur memelihara sistem yang baik (Van Hoek, 2012), dan kemampuan mengelola sistem informasi dengan baik (Towill 2013). Sehingga, perhitungan Return On Investment (ROI) yang tidak layak menyebabkan proyek VMI dibatalkan (McBeath, 2012).

Dapat disimpulkan beberapa faktor penentu keberhasilan dan penghambat dalam menerapkan VMI sebagai berikut:

Tabel 1. Faktor Keberhasi@an dan Penghambat VMI

\begin{tabular}{|l|l|}
\hline Keberhasilan & Penghambat \\
\hline $\begin{array}{l}\text { Pengurangan proses } \\
\text { pemesanan inventori }\end{array}$ & $\begin{array}{l}\text { Komitmen dan } \\
\text { kemauan pemasok } \\
\text { dan } \\
\text { dalam menjalankan }\end{array}$ \\
$\begin{array}{l}\text { Menghilangkan } \\
\text { kesalahan } \\
\text { penyampaian } \\
\text { informasi }\end{array}$ \\
VMI
\end{tabular}

\begin{tabular}{|l|l|}
\hline $\begin{array}{l}\text { Permintaan konsumen } \\
\text { akhir diketahui semua } \\
\text { pihak di dalam rantai } \\
\text { pasok }\end{array}$ & $\begin{array}{l}\text { Biaya investasi } \\
\text { sistem informasi }\end{array}$ \\
$\begin{array}{l}\text { Pengiriman inventori } \\
\text { kepat waktu } \\
\text { pembagian risiko } \\
\text { inventori }\end{array}$ \\
$\begin{array}{l}\text { Berkurangnya } \\
\text { kebutuhan } \\
\text { penyimpanan fisik } \\
\text { inventori di pemasok }\end{array}$ \\
$\begin{array}{l}\text { Mengurangi proses } \\
\text { penanganan } \\
\text { inventori } \\
\text { konsumen di }\end{array}$ \\
\hline
\end{tabular}

\section{METODE PENELITIAN}

Penelitian dilakukan dengan metode case study berbasis pendekatan deskriptif di industri farmasi pada perusahaan $X$ (konsumen) dan perusahaan $\mathrm{Y}$ (pemasok), yang juga statusnya sebagai anak perusahaan dari X. Perısahaan X (konsumen) adalah salah satu perusahaan farmasi terbesar di Indonesia. Pabriknya terletak di kawasan Cikarang, Jawa Barat, Ada ratusan jenis produk obat yang dihasilkan setiap tahunnya. Bahan mentah obat diperoleh dari dalàn dan luar negeri. Bahan baku kemasan yang termasuk dalam Pareto dihasilkan oleh perusahaan Y (pemasok). Pemasok terletak di daerah Bekasi, Jawa Barat. Menerapkan VMI memberikan banyak keuntungan karena instensitas komunikasi dan pengiriman inventori diantara kedua perusahaan. Maka, penelitian untuk perusahaan $\mathrm{X}$ dan $\mathrm{Y}$ memberi gambaran yang lebih menyeluruh mengenai penerapan VMI.

Kronologi penulisan penelitian ini dimulai dengan deskripsi kasus, dilanjutkan dengan keterkaitan antara perusahaan $\mathrm{X}$ dan $\mathrm{Y}$, 
metode pengumpulan data, dan metode analisis data.

\section{i. Kondisi perusahaan $\mathrm{X}$ dan $\mathrm{Y}$}

Meski keduanya ada di satu grup perusahaan yang sama, kolaborasi permintaan dan pengiriman barang tidak selalu berjalan mulus. Begitu juga dengan lokasi perusahaan yang relatif dekat, lead time pengiriman inventori masih saja berfluktuasi tinggi, mulai dari dua jam sampai tiga hari. Penyebabnya adalah kemasan yang dikirim seringkali tidak memenuhi standar kualitas yang disepakati, dikarenakan kondisi penyimpanan yang tidak kondusif dan sistem pengendalian kualitas di pemasok masih kurang baik.

Seiring meningkatnya bisnis konsumen, otomatis produksi dari pemasok harus naik. Dengan kondisi penyimpanan inventori di pemasok yang kurang kondusif, maka akan meningkatkan risiko inventori rusak. Selain itu, kapasitas penyimpanan inventori di pemasok terbatas.

Dikarenakan statusnya sebagai anak perusahaan, maka pemasok selalu menanggung kesalahan penyimpanan dan pengiriman inventori. Di sisi lain, konsumen kurang peduli dengan konerja pemasok.

Peluang untuk efisiensi ini dipecahkan dengan menerapkan VMI untuk menyelesaikan masalah pengiriman, menjaga kualitas inventori, dan keterbatasan ruang penyimpanan di pemasok.

\section{ii. Pengumpulan dan Analisa data}

Penelitian berbasi case study mampu menggali informasi secara mendetil dan mendalam terkait subyek penelitian. Kasus diangkat ketika perusahaan $\mathrm{X}$ dan $\mathrm{Y}$ menjalankan konsep VMI untuk mengefisienkan pengelolaan inventori mereka dengan konsep VMI. Sebelum menerapkan VMI, metode penyimpanan inventori di pemasok tidak kondusif sehingga sering terjadi pengiriman tidak tepat waktu, dan sering terjadi kesalahan dalam menentukan kapan harus melakukan pengisian kembali inventori.

Penelitian ini membahas perilaku organisasi/perusahaan dalam menangani satu isu khusus, yaitu inventori (metode single level analysis). Data primer diperoleh melalui wawancara kepada para karyawan di kedua perusahaan (sebagai unit analisis) yang bertanggungjawab dengan keberhasilan VMI (metode single case design). Unit analisis disini adalah kelompok karyawan dari pemasok (perusahaan Y) dan konsumen (perusahaan X). Sumber informasi diperoleh dari informan yang memiliki pengetahuan mengenai inventori dan bertanggungjawab atas keberhasilan VMI dikedua perusahaan. Informan adalah karyawan dari kedua perusahaan yang menempati posisi: Manager Supply Chain, Manajer Produksi dan Inventori, Asisten Manajer Keuangan dan observasi lapangan kepada karyawan terkait. Wawancara dilakukan secara individu, dimana setiap responden mendeskripsikan proses pada divisi masing-masing dan kaitannya dengan proyek VMI.

Pewawancara diakomodir dengan interview guide untuk mengarahkan sesi wawancara sesuai arah yang benar, namun masih membuka peluang bagi informan untuk mengembangkan informasi yang disediakan. Waktu wawancara adalah pada jam kerja di pagi hari ketika informan masih dalam kondisi terbaiknya untuk bekerja.

Tahap pertama wawancara untuk mengumpulkan informasi. Setelah itu, informasi dibandingkan dengan teori, kemudian divalidasi/dengan wawancara dengan divisi lain dan observasi lapangan. Tahap kedua wawancara untuk inemvalidasi akhir dari semua informasi yang diperoleh.

Kekurangan metode wawancara adalah informasi yang disediakan tergantung pada sudut pandang dari pihak yang 
diwawancara, maka diperlukan sumber informasi dari pihak pemasok dan konsumen sebagai validasi (Yin, 2003). Untuk meningkatkan validitas dan reliabilitas dari data yang didapatkan, maka dilakukan proses wawancara dengan tahapan yang sama kepada pihak pemasok dan konsumen. Informasi yang diperoleh dari wawancara kepada semua pihak terdiri dari:

Tabel 2. Sumber Informasi, Metode Pengumpulan Informasi, dan Informasi Yang Diperoleh

\begin{tabular}{|c|c|c|}
\hline Informan & Metode & $\begin{array}{l}\text { Informasi yang } \\
\text { diperoleh }\end{array}$ \\
\hline $\begin{array}{l}\text { Manager } \\
\text { supply chain }\end{array}$ & $\begin{array}{l}\text { Wawancara } \\
\text { mendalam }\end{array}$ & \begin{tabular}{lr} 
- Proses & bisnis \\
antara & pemasok dan \\
konsumen. & \\
- Tipe & kolaborasi \\
\multicolumn{2}{c}{ pemasok- konsumen }
\end{tabular} \\
\hline $\begin{array}{l}\text { Manajer } \\
\text { Produksi dan } \\
\text { Inventori }\end{array}$ & $\begin{array}{l}\text { Wawancara } \\
\text { mendalam }\end{array}$ & \begin{tabular}{lr} 
- & Proses r peramalan, \\
pemesanan & dan \\
penanganan inventori. \\
- & Intensitas \\
\multicolumn{2}{c}{ komunikasi } \\
\multicolumn{2}{c}{ information sharing. }
\end{tabular} \\
\hline $\begin{array}{l}\text { Asisten } \\
\text { Manajer } \\
\text { Keuangan }\end{array}$ & $\begin{array}{l}\text { Wawancara } \\
\text { mendalam }\end{array}$ & $\begin{array}{ll}\text { Proses } & \text { pembayaran } \\
\text { penagihan } & \text { harga jual } \\
\text { inventori. } & \end{array}$ \\
\hline $\begin{array}{l}\text { Karyawan } \\
\text { yang } \\
\text { menangani } \\
\text { inventori }\end{array}$ & $\begin{array}{l}\text { Mempelajari } \\
\text { dokumen } \\
\text { perusahaan, } \\
\text { observasi }\end{array}$ & $\begin{array}{l}\text { Alur proses penanganan } \\
\text { inventori }\end{array}$ \\
\hline $\begin{array}{l}\text { Literature } \\
\text { berupa text } \\
\text { book }\end{array}$ & $\begin{array}{l}\text { Mempelajari } \\
\text { dan mengkaji } \\
\text { teori atau } \\
\text { penelitian } \\
\text { terdahulu. }\end{array}$ & \\
\hline
\end{tabular}

Analisis data dilakukan secara kronologis, mulai dari tahapan penerapan VMI dan evaluasi keberhasilan VMI. Proses analisa dilengkapi dengan mendeskripsikan kondisi penerapan VMI, membandingkan kunci keberhasilan dan penghambat, dan kesesuaian dengan teori. Proses ini merupakan pendekatan yang ampuh dan kaya akan penjelasan argumentative, berdasarkan teknik analisa data collection, data display, dan conclusion (Vigtil, 2014).

\section{HASIL DAN PEMBAHASAN}

Kerjasama pemasok-konsumen tidak bersifat eksklusif, artinya pemasok juga menjual output produksinya kepada beberap perusahaan lain. Perusahaan X sebagai induk perusahaan $\mathrm{Y}$ harus diutamakan permintaannya. Sekitar $70 \%$ output Y dijual ke X.

Obyektif sebagai pemasøk adalah memenuhi semua permintaan konsumen. Ketika permintaan tinggi, pemasok seringkali bekerja lembır. Ketika permintaan turun, pemasok bertanggung jawab mengatur waktu produksinya sendiri. Jika ada produk terkirim yang rusak, pemasok bertanggungjawab menggantinya dengan yang baru. Sementara itu, obyektif dari konsumen adalah membina kerjasama dengan pemasok, membantu pemasok meningkatkan efisiensi pengelolaan perusahaan, termasuk di bidang sumber daya manusia dan inventori. Karena konsumen menghasilkan barang jadi dan dijual langsung kepada konsumen akhir, maka sistem dan standar pengendalian kualitas yang tinggi menjadi tanggungjawab pemasok dan konsumen.

Ketika menerapkan VMI, kedua perusahaan memiiliki komitmen dan kemauain menjalani VMI, memahami dan sepakat bekerja sama mengelola inventori, berbagi informasi, dan menanggung risiko inventori bersama-sama. Tahap pertama adalah menentukan inventori mana sajakah yang akan diperlakukan dalam sistem VMI, yaitu dengan memilih jenis inventori Pareto. Inventori Pareto ini akan mengurangi kebutuhan ruang penyimpanan inventori di pemasok dan mengurangi biaya pengelolaan inventori secara signifikan. Inventori yang tidak termasuk dalam Pareto menggunakan sistem pemesanan inventori tradisional, yaitu inventori dipesan dalam jumlah besar 
untuk memenuhi kebutuhan beberapa bulan ke depan. Hal ini tidak memberatkan biaya inventori karena nilainya yang relatif murah. Berikutnya adalah menentukan titik pengisian kembali inventori (re-order level) yang efisien bagi pemasok dan konsumen dengan pertimbangan kapasitas produksi di pemasok, tenggat waktu pengiriman inventori, ketersediaan moda transportasi, infrastuktur proses penerimaan dan penyimpanan inventori di konsumen, infrastruktur proses administrasi. Untuk mendukung ini, dipersiapkan sebuah sistem informasi terintegrasi yang secara bersamaan digunakan oleh pemasok dan konsumen. Berikutnya adalah kesiapan tenaga kerja dan standar kerja menjalani VMI, termasuk pelatihan dan periode transisi.

Tahap kedua adalah mempersiapkan lokasi dan kapasitas penyimpanan inventori VMI. Karena VMI ditekankan pada perubahan sistem, maka lokasi penyimpanan inventori tidak dikhususkan, tidak terpisah dengan inventori yang dikelola tanpa VMI. Lokasi penyimpanan inventori di konsumen dikelompokkan berdasarkan pemasoknya. Yang membedakan adalah status inventori pada sistem informasi bahwa inventori tertentu menggunakan sistem pengisian VMI. Status ini menunjukkan jenis inventori, kebutuhan per bulan, nomor lokasi penyimpanan, dan penanggungjawabnya. Kapasitas penyimpanan pun memadai karena konsumen mempersiapkan gudang penyimpanan skala besar untuk antisipasi kebutuhan sampai beberapa tahun ke depan.

Tahap ketiga adalah investasi infrastruktur, termasuk sistem informasi, sistem kontrol, reward dan punishment, kewajiban pemasok dan konsumen. Pemasok wajib memantau perkembangan pemakaian inventori, dan konsumen wajib menyediakan lokasi penyimpanan yang memadai serta pembayaran harga beli inventori sesuai jadual term of payment. Keduanya wajib menanggung risiko inventori selama periode setelah inventori diterima dan disimpan di gudang konsumen sampai inventori dikonsumsi. Tanggungjawab ini berupa pembagian biaya risiko hilang, rusak, dan asuransi. Kedua pihak sepakat berbagi tanggungjawab biaya-biaya tersebut. Biaya penyimpanan fisik ditanggung oleh konsumen. Investasi berikutnya adalah jaringan sistem informasi dengan perangkat lunak yang handal, aman, dan terintegrasi antara pemasok dan konsumen. Informasi pada sistem harus mampu diperbaharui setiap saat hanya oleh pihak yang bertanggungjawab terhadap pengelolaan inventori. Data dapat diketahui oleh divisi keuangan untuk pelaporan, namun divisi keuangan tidak dapat merubah isi data.

Proses dari VMI ini adalah konsumen mengirim informasi kebutuhan dan peramalan kebutuhan invetori kepada pemasok setiap bulannya. Informasi ini berupa jenis, jumlah, dan waktu pemakaian barang. Pemasok mengirim informasi berupa jadual kesanggupan mengirim inventori. Inventori yang tidak sepenuhnya bisa dipenuhi konsumen tetap diperlakukan dengan sistern VMI. Nanun kekurangan ini akan dipenuhi pada periode mendatang atau konsumen mencari pemasok lain. Moda transportasi pengifiman inventori menjadi tanggungan bersama. Pemasok tidak mendedikasikan moda transportasi khusus, karena pengiriman dapat dilakukan bersamaan dengan inventori lain yang tidak termasuk dalam proyek VMI. Hal ini karena pada dasarnya pemasok mengirim produknya kepada konsumen secara harian atau maksimal dua hari sekali. Hal ini sejalan dengan penemuan dari Lockström bahwa ketersediaan sarana transportasi yang terjadual dan intensif pengirimannya akan mendukung keberhasilan VMI (Lockström, 2010).

Pengawasan terhadap inventori VMI dilakukan lebih intensif dibandingkan kontrol untuk inventori jenis lain, mengingat nilainya yang besar dan pemakaiannya yang instensif. Setiap kali ada pemakaian inventori, konsumen memperbaharui data 
inventori yang secara otomatis akan terkirim ke pemasok. Pemasok mengontrol ketersediaan inventori dan ketika mendekati titik pengisian inventori (re-order level), pemasok mempersiapkan pengiriman inventori berikutnya. Di setiap akhir bulan, pemasok mengirim data pemakaian inventori kepada konsumen. Tenggat waktu pembayaran khusus inventori VMI disepakati satu bulan setelah akhir bulan sebelumnya dari pemakaian inventori. Tenggat waktu pembayaran inventori lainnya dilakukan selama dua sampai tiga bulan setelah pemakaian. Setiap tiga bulan, pemasok dan konsumen menilai keberhasilan dari proyek VMI, membahas masalah yang muncul, kemudian mencari solusinya.

Berikut ini adalah kesimpulan dari hasil wawancara mengenai faktor keberhasilan dan penghambat dalam menerapkan VMI.

i. Komitmen dan kemauan pemasok dan konsumen dalam menerapkan VMI.

Pada dasarnya, pemasok dan konsumen memiliki perhatian yang besar untuk terus berkembang bersama dalam menghadapi persaingan usaha, meksipun perbedaan kualitas infrastruktur dan sumber daya manusianya mengakibatkan kerjasama tidak selalu berjalan mulus.

Pemasok dan konsumen mampu bekerja sama dengan baik dalam mendesain dan menjalankan ketiga tahap persiapan VMI. Pertemuan dijalankan secara intensif secara mingguan. Hambatan yang muncul adalah kesiapan tenaga kerja di pemasok yang kurang kualitasnya. Konsumen turut membantu pemasok dengan memberi pelatihan dan bimbingan. Hambatan ketika VMI dijalankan adalah disiplin dan budaya kerja yang berbeda, dimana disiplin kerja di pemasok tidak sebaik di konsumen. Situasi ini diakomodir dengan pengenalan budaya kerja, memantapkan disiplin, menegur, serta pengawasan langsung oleh konsumen kepada pemasok. Penerapan VMI pada organisasi dengan budaya kerja yang berbeda membutuhkan proses penyatuan pandangan terlebih dahulu (Waller, 2009).

Secara berkala, pemasok dan konsumen menilai kinerja masing-masing, yaitu: ketepatan permintaan dari konsumen kepada pemasok, ketepatan pengiriman barang dari pemasok kepada konsumen, jumlah produk rusak yang minim, dan ketepatan pembayaran oleh konsumen kepada pemasok.

\section{ii. Berkurangnya proses pemesanan} inventori.

Sebelum VMI diterapkan, konsumen mengirim kebutuhan inventori setiap bulan dan peramalan pemakaian inventori untuk tiga bulan ke depan. Pada bulan berjalan, konsumen melakukan kontak harian dengan pemasok untuk memastikan inventori yang diminta akan dikirim sesuai jadualnya. Informasi disampaikan secara manual (melalui e-mail, fax). Dibutuhkan beberapa waktu sebelum pemasok menerima informasi permintaan inventori secara lengkap. Konsumen membuat sendiri perkiraan kebutuhan dan titik pemesanan kernbali untuk inventori. Hal ini tidak dikoordinasikan dengan kapasitas produksi dan ruang penyimpanan inventori di pernasok.

Proses monitoring dilakukan oleh konsumen melalui sebuah tim khusus di divisi pembelian (purchasing) dan oleh pemasok di divisi produksi. Proses monitoring ini cukup memakan waktu ketika terjadi keterlambatan pengiriman dan pengisian inventori. Akibatnya, proses produksi terhambat.

Dengan menerapkan VMI, konsumen dan pemasok mendiskusikan dan menyepakati jumlah inventori yang dikirim setiap bulan dengan pertimbangan kapasitas produksi dan ruang penyimpanan inventori di kedua pihak. Untuk mendukung ini, dilakukan proyek pendahuluan berupa efisiensi dan 
integrasi sistem pergudangan di pemasok dan konsumen. Setiap bulan, konsumen mengirim informasi kebutuhan inventori dan peramalan kebutuhan untuk tiga bulan ke depan. Khusus ketersediaan inventori VMI diakomodasi dalam sistem informasi yang mengintegrasikan pemasok dan konsumen sehingga pemasok. Ketika konsumen menggunakan inventori, konsumen memperbaharui data inventori pada sistem informasi, kemudian status kepemilikan beralih dari pemasok kepada konsumen. Sistem informasi secara otomatis memperbaharui data inventori yang dapat dilihat oleh divisi produksi dan inventori, pembelian, dan supply chain di kedua perusahaan. Dengan sistem VMI, hanya divisi produksi di pemasok yang mengawasi sisa inventori di konsumen. Ketika mencapai titik pemesanan inventori, divisi produksi segera mempersiapkan inventori yang akan dikirim kepada konsumen. Proses ini dilakukan tanpa ada proses permintaan secara manual dari konsumen. Kedua pihak mengontrol kelancaran pengiriman inventori melalui sistem informasi: apakah inventori sudah dikirim pemasok, apakah inventori sudah diterima konsumen, berapa lama inventori tersimpan di konsumen, dan apakah inventori sudah dikonsumsi.

Dengan demikian, proses permintaan dan penerimaan inventori dilakukan sepenuhnya dengan bantuan sistem, tanpa adanya proses manual yang dilakukan kedua perusahaan. Informasi kebutuhan inventori pun diperoleh pemasok saat itu juga, tanpa perlu waktu untuk mengumpulkan informasi sampai lengkap (yang mana sebelum proyek VMI dilakukan manual dengan menunggu informasi melalui e-mail dan fax).

Dengan sistem informasi yang terintegrasi, maka tidak muncul kesalahan penyampaian informasi. Namun demikian, dibutuhkan kedisiplinan konsumen dalam memperbaharui status inventori setiap saat (McBeath, 2012). Menurut Manajer
Inventori, sharing informasi tidak selalu berjalan lancar karena pemasok terkadang tidak menyampaikan data produksi secara lengkap dan konsumen menekan pemasok untuk memenuhi keinginannya. Hal ini karena status konsumen sebagai induk perusahaan dari pemasok. Konsumen sendiri kurang membantu pemasok dalam membangun sistem produksi yang diharapkan. Kekurangan ini dapat mengakibatkan penerapan VMI tidak menjadi lebih efisien dibandingkan metode pemesanan inventori lainnya (Towill, 2013). Namun demikian, antara pemasok dan konsumen selalu berkomitmen dalam memantau keberhasilan VMI serta mencari solusi terhadap hambatan- hambatan yang muncul.

iii. Berkurangnya kebutuhan penyimpanan fisik inventori di pemasok.

Sebelum VMI diterapkan, konsumen dan pemasok menyimpan inventori untuk memenuhi kebutuhan masing-masing tanpa melihat jumlah inventori di luar gudang mereka. Pertimbangan dalam menyediakan inventori adalah fluktuasi kebutuhan konsumen, tingkat produksi di pemasok, dan tenggat waktu pengiriman inventori dari pemasok kepada konsumen. Dengan statusnya sebagai induk perusahaan dari pemasok, konsumen seringkali merubah jumlah kebutuhan inventori dan melimpahkan biaya dan risiko inventori kepada pemasok. Biaya yang ditanggung pemasok dengan sendirinya akan mengurangi keuntungan pemasok. Pada akhirnya, konsumen sendiri yang menerima dampak pengurangan keuntungan.

Dengan meningkatnya risiko dan masalah pada inventori, maka perlu tindakan untuk mengurangi jumlah dan biaya inventori total yang ditanggung oleh konsumen sekaligus pemasok. Perlu diingat juga bahwa biaya inventori menyumbang sekitar 25\% dari harga jualnya (Harrison, 2012). Maka, pengelolaannya harus 
dilakukan terintegrasi. Antara pemasok dan konsumen tidak dapat berjalan masingmasing jika ingin mencapai keuntungan bersama.

Selain mengintegrasikan informasi, VMI pun mengintegrasikan kebutuhan dan ketersediaan inventori yang disimpan di setiap perusahaan yang bekerja sama (Vigtil, 2014). Dalam penelitian ini, pemasok dan konsumen bekerja sama mengolah data kebutuhan inventori selama satu tahun ke depan, kemudian dirinci menjadi kebutuhan per bulan. Data ini diterjemahkan menjadi data produksi, kebutuhan inventori setiap bulan, dan kapasitas penyimpanan inventori. Dengan integrasi ini, maka kebutuhan inventori ditujukan untuk kebutuhan konsumen. Konsumen tidak menyimpan inventori lebih demi mengakomodasi keterlambatan pengiriman dari pemasok, pemasok pun tidak menyimpan inventori berlebih akibat antisipasi tenggat waktu dan fluktuasi permintaan konsumen.

Secara total, inventori yang disimpan di pemasok dan konsumen menjadi lebih sedikit. Terlebih lagi, inventori yang disimpan di pemasok berkurang banyak karena sebagian besar inventori dialihkan ke gudang konsumen. Akibatnya, biaya penyimpanan dan biaya mengontrol inventori di konsumen meningkat. Sebaliknya, biaya tetap gudang di konsumen per satuan unit inventori menjadi lebih murah karena menampung lebih banyak inventori. Gudang konsumen menyediakan ruang yang cukup untuk menampung dan mengawasi inventori dengan baik.

Biaya lain yang berkurang adalah pembagian biaya risiko kehilangan atau rusaknya inventori selama disimpan oleh konsumen, biaya penyimpanan dan mengontrol inventori di pemasok.

Manajer Supply Chain di perusahaan pemasok dan konsumen sepakat bahwa bertambahnya biaya pada konsumen iini dapat diakomodir dengan berkurangnya biaya inventori di pemasok. Perhitungan ini sudah dijalankan oleh perusahaan. Sehingga, perhitungan biaya inventori selayaknya mempertimbangkan biaya total inventori yang ditanggung oleh perusahaan yang terlibat (Towill, 2013).

iv. Permintaan konsumen akhir diketahui semua pihak di dalam rantai pasok.

Dengan terintegrasinya informasi, maka perkiraan akhir (barang jadi yang akan dijual) dapat diketahui oleh pemasok dan konsumen. Sebelum menerapkan VMI, kebutuhan akhir hanya diolah dan diketahui oleh konsumen, dan pemasok hanya menerima informasi kebutuhan konsumen. Jumlah kebutuhan inventori yang diminta konsumen kepada pemasok terdiri dari jumlah barang yang akan dijual ditambah dengan inventori pengaman jika ada pengiriman yang terlambat dari pemasok. Akibatnya inventori total harus disediakan banyak. Kondisi ini dirasakan oleh Manajer Inventori di pemasok pada masa awal menerapkan VMI.

Ketidaksesuaian informasi mengenai inventori sesungguhnya yang harus disediakan pemasok dan konsumen mengakibatkan fenomena bullwhip effect (Towill, 2013). Dalam fenomena ini, entiti pada posisi yang semakin mendekati hulu akan menyediakan inventori lebih besar dari yang dibutuhkan demi mengantisipasi fluktuasi kebutuhan konsumennya dan mengakomodir tenggat waktu pengiriman inventori. Fluktuasi di sisi hilir akan mengakibatkan fluktuasi inventori yang semakin besar di posisi hulu. Efeknya adalah beban proses produksi dan penanganan inventori berfluktuasi dan tidak efisien bagi perusahaan.

Fenomena ini dapat dikurangi dengan berbagi informasi kebutuhan inventori kepada semua pihak di dalam rantai pasok, sehingga pemasok mengetahui perkiraan kebutuhan untuk barang jadi, dapat mempersiapkan rencana produksi, dapat melakukan pembelian bahan mentah 
dengan lebih efisien, dan penanganan inventori yang lebih baik (Simchi-Levi. 2014). Dengan demikian, pengiriman inventori kepada konsumen menjadi lebih terjamin

Selain data penjualan yang dibagi kepada semua pihak, informasi lain yang wajib diketahui adalah jumlah minimum dan maksimum inventori. Ketika jumlah inventori mencapai dua kondisi ini, perangkat lunak dalam sistem informasi akan memberi peringatan. Ketika jumlah inventori mencapai titik minimum, konsumen bertanggungjawab mengingatkan pemasok untuk segera mengisi kembali inventori. Dalam kondisi ini, pemasok wajib memprioritaskan produksi dan pengiriman inventori yang sudah mencapai jumlah minimum. Ketika mencapai jumlah maksimum, konsumen berhak menolak inventori yang dikirim pemasok, dan pemasok berhak mengingatkan konsumen untuk memperbaiki sistem peramalan kebutuhan inventori.

\section{KESIMPULAN}

Pada studi kasus di industri farmasi dimana pemasok merupakan anak perusahaan, VMI mampu menyediakan keuntungan operasional dan stratejik, yaitu: mengurangi kegiatan rutin pemesanan inventori, mengurangi kebutuhan ruang penyimpanan, menjamin ketersediaan inventori, memperkuat kolaborasi antara entiti di dalam rantai pasok karena keterbukaan diantara entiti serta membuka peluang perbaikan.

Untuk mencapai ini, pemasok harus menjaga kualitas barang yang akan dikirim ke konsumen. Sangat penting untuk memahami permintaan dan persyaratan kualitas produk sebelum pemasok menjalankan produksinya. Infrastruktur dan keterbukaan berbagi informasi pun menjadi faktor penting untuk keberhasilan VMI.
Kendala yang dihadapai berupa: sistem produksi dan kualitas antara pemasok dan konsumen tidak sepadan, dibutuhkan penyesuaian material handling di pemasok dan konsumen.

Disarankan kolaborasi perusahaan dalam satu induk perusahaan yang sama seharusnya menjadi pemicu kerjasama yang lebih erat, bukan sebagai kondisi menekan anak perusahaan. Keuntungan yang diperoleh dari menerapkan VMI harus dapat dihitung baik sehingga mampu mengakomodir biaya-biaya yang dapat muncul, seperti meningkatnya biaya penyimpanan inventori di konsumen.

Meski demikian, pada kasus ini pemasok dan konsumen sepakat untuk terus memperbaiki kerjasama mereka. Pemasok dan konsumen sepakat bahwa menerapkan sebuah sistem baru seperti VMI membutuhkan komitmen dan kolaborasi jangka panjang, serta saling mendukung untuk menghindari hal-hal yang tidak diinginkan.

\section{DAFTAR PUSTAKA}

\section{Paper dalam jurnal}

[1] Ellinger. 2013. Automatic Replenishment Programs and Level of Involvement: Performance Implications, International Journal of Logistics Management, Vol. 10, No. 1, pp 25-36.

[2] Lapide, L. 2011. New developments in business forecasting, The Journal of Business Forecasting Methods \& Systems, Vol. 20, Iss. 4, pp 11, 12 and 36.

[3] Towill, D.R. 2013. Vendor-managed inventory and bullwhip reduction in a two-level supply chain, International Journal of Operations \&/Production Management,Vol. 23 No. 6. 
[4] Vigtil, Astrid. 2014. A framework for Modelling of Vendor Managed Inventory, Norwegian University of Science and Technology.

[5] Waller, M. Johnson. 2009. Vendormanaged inventory in the retail supply chain, Journal of business logistics, Vol. 20, No. 1.

[6] Whang, S. 2010. Information distortion in a supply chain: the bullwhip effect, Management Science, Vol. 43 No. 4, pp. $546-58$.

\section{Buku}

[7] Harrison, A, \& van Hoek, R.. 2012. Logistics management and strategy, Pearson Education, Prentice Hall.

[8] Lockström et al. 2010. Antecedents to Supplier Integration in the Automotive Industry: A Multiple-Case Study of Foreign Subsidiaries in China Journal of Operations Management, pp 240-256.

[9] Simchi-Levi. 2014. Designing and managing the supply chain, concepts, strategies and case studies, McGraw Hill.

\section{Laporan Penelitian}

[10] Mattson. 2012. Logistik i försörjningskedjor Studentlitteratur, Lund.

[11] McBeath, Bill. 2012. The truth about VMI - revelations and recommendations, ChainLink Research study on VMI in the High tech Supply chain, ChainLink Research.

[12] Sitompul, Carles. 2013. Implementasi model persediaan yang dikelola pemasok (Vendors Managed Inventory) dengan banyak retailer, Lembaga Penelitian dan Pengabdian kepada Masyarakat Universitas Katolik Parahyangan. 